\title{
空間的に広がりがあるオブジェクトのトラッキングにおいて 参照点検出がトラッキング運動に与える影響
}

\author{
○上田彩子 ${ }^{1}$, 中島亮一 ${ }^{1}$, 井関龍太 ${ }^{1}$, 岩井律子 ${ }^{1}$, 熊田孝恒 ${ }^{1,2}$ \\ ( ${ }^{1}$ 理化学研究所 理研BSI-トヨタ連携センター・2 京都大学 $)$ \\ キーワード : 視覚運動協応・トラッキング課題・参照点の検出
}

\begin{abstract}
Influence of reference-points detection on visuomotor tracking task using spatially extended objects Sayako UEDA ${ }^{1}$, Ryoichi NAKASHIMA ${ }^{1}$, Ryuta ISEKI ${ }^{1}$, Ritsuko IWAI ${ }^{1}$ and Takatsune KUMADA ${ }^{1,2}$
\end{abstract} ( ${ }^{1}$ RIKEN BSI-Toyota Collaboration Center, RIKEN Brain Science Institute, ${ }^{2}$ Kyoto University)

Key Words: visuomotor coordination, tracking task, reference-points detection

\section{目 的}

環境イベントに対応した適切な運動を生成するうえで, 視 覚運動協応は重要である。視覚運動協応のメカニズムを検討 する代表的な課題に, 運動する目標(ターゲット)をジョイス ティックなどの入力装置でコントロールできる自己（エフェ クター) でトラッキングする課題がある。上田ら（2015）は, オブジェクトの大きさがトラッキングに与える影響について 検討し，オブジェクトが大きくなるほどトラッキング成績が 低下するが，エフェクターがターゲットより大きい場合には 成績の低下具合が小さいこと（エフェクター優位効果）を発 見した。エフェクター優位効果の原因として, ターゲットと エフェクターで，参照点を検出してから運動に協応させるま での過程に違いがある可能性がある。そこで, 本研究では, どちらか一方の参照点の検出を必要とする課題を設定し, こ の可能性について検討した。その際, 次の仮説を設定した。 仮説 : ターゲットの参照点を検出して運動に協応させる過程 のほうが，エフェクターにおける過程よりも難しい。 方 法

実験参加者 96 名 (男性 41 名, 女性 55 名, 平均年齢 38.6 歳) 刺激 参照点検出が必要なターゲットとエフェクターとして 3 段階の大きさのオブジェクト (compact, medium, large), および参照点検出が必要でないターゲットとエフェクターと して点刺激（point）を設定した。

実験デザイン (1) ターゲット参照点検出課題と (2)エフェク ター参照点検出課題を設定し, ブロックデザインで実施した。 (1) は常にエフェクターが, (2) は常にターゲットが点刺激で, 互いに組み合わせるオブジェクトの大きさが 3 条件あった。 結果の予測 仮説のとおり, ターゲットの参照点を検出して 運動に協応させるほうが，エフェクターよりも難しいのであ れば，(2)よりも(1)で成績が悪くなり，(1)と（2）の間で，才 ブジェクトサイズの増加に伴う成績の低下具合に違いが認め られるはずである。

手続き 実験はPCを用いて個別で実施した。画面上には, 夕 ーゲット（上）とエフェクター（下）が提示された。実験参 加者の課題は, 正弦波の合成に基づいて不規則に左右に運動 するターゲットの中央に，エフェクターの中央を，できるだ け差が小さくなるように合わせることであった。1 試行は約 17 秒間継続した。各課題の本試行前に 3 回の練習試行を実施 した。各課題の本試行は 12 試行 (3 条件 $\times 4$ 試行) であった。

\section{結 果と 考 察}

成績の指標としてトラッキングエラー (RMSE) を算出した。 仮説を検証するため, 課題とオブジェクトの大きさを参加者 内要因とした分散分析を実施した結果，（1）と (2)でともに, オブジェクトの大きさが増加するほど成績が低下することが 確認できたが, (1)と (2)で, 成績の違いや, オブジェクトサ
イズの増加に伴う成績の低下具合に違いは認められなかった (Fig1)。そのため, ターゲットの参照点を検出してから運動 に協応させる過程のほうが, エフェクターについての過程よ りも難しいわけではないことが示された。したがって, エフ エクター優位効果は, ターゲットとエフェクターの参照点を 同時に検出す る場合に特異 的なものであ る可能性が高 い。

ではなぜ 参照点同時検

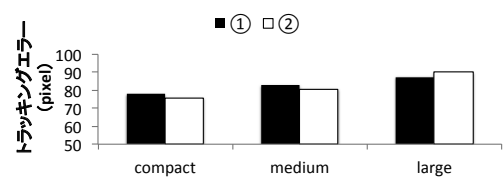

Fig 1 トラッキングパフォーマンス
出時にエフェクター優位効果が見られたのか。その理由とし て, 参照点同時検出過程に対して, ターゲットとエフェクタ 一についての参照点検出から運動協応への過程の関与度合い が異なる可能性がある。もし関与度合いが異なるならば，上 田ら (2015)の課題成績と, 本研究課題の (1) (2)の成績の相関 の強さに違いが見られるはずである（関与が大きいほど，強 い相関が見られると考えられる)。上田ら (2015)の課題成績と (1) (2)の成績について相関係数を算出した結果, 両者とも上 田ら (2015)の課題成績と高い相関を示したが, 有意に(1)の相 関係数が大きかった (Fig 2, (1)： $r=.84>(2): r=.67)$ 。そ のため, 参照点同時検出時にどちらの過程も関与しているが, その度合いはターゲットの参照点を検出して運動に協応させ る過程のほうが大きいことが示された。つまり，エフェクタ 一優位効果は, こうした過程の関与度合いの違いが成績に反 映されたためと考えられる。エフェクターについての過程の 関与度合いが低かったことの理由として, エフェクターにつ いての過程は, 順モデルによる予測機能によってサポートさ れている可能性が考えられる。順モデルとは, エフェクター の巧みな操作の理論的なモデルである内部モデルのひとつで あり, CNS からエフェクターへの入出力方向と同じ入出力関 係を持ち、運動指令 (入力) から引き起こされる動作 (出力) の予測を可能にする。
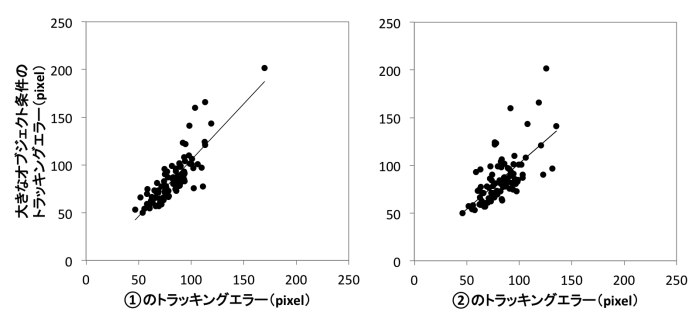

Fig 2 上田ら(2015) と各課題の相関 